\title{
Adsorption of Cu (II) and Cd (II) onto Activated Carbon Prepared from Pumpkin Seed Shell
}

\author{
Almaz Kemal, Khalid Siraj*, Wondmagegn H. Michael \\ Department of Chemistry, College of Natural Sciences, Jimma University, P. O. Box 378, Jimma, Ethiopia.
}

\section{A R T I C LEDET AILS}

\section{Article history:}

Received 04 March 2019

Accepted 24 March 2019

Available online 05 May 2019

\section{Keywords:}

Heavy Metals

Activated Carbon

Pumpkin Seed Shells

\begin{abstract}
A B S T R A C T
Present study discusses the removal of heavy metal contaminants from an aqueous solution using orthophosphoric acid activated pumpkin seed shells derived activated carbon (PSS-AC). The activation was done by heating the mixture in an electrical furnace at $800{ }^{\circ} \mathrm{C}$ for $3 \mathrm{~h}$. Adsorption experiments were carried out as a function of $\mathrm{pH}$, contact time, initial $\mathrm{Cu}$ (II) and Cd (II) ion concentrations, adsorbent dosage and temperature of the solution for the metal ion removal. The equilibrium and kinetic studies data were fitted better for the Langmuir isotherm model and pseudo-second order model respectively. Thermodynamic parameter obtained for $\mathrm{Cu}$ (II) and Cd (II) ions adsorption suggests the reaction to be non-spontaneous, feasible; and endothermic between temperatures of $25^{\circ} \mathrm{C}$ and $45^{\circ} \mathrm{C}$.
\end{abstract}

\section{Introduction}

Water is one of the most vital resources for all living organisms. It is an important component for industrial processes, agricultural production and domestic uses on the Earth. Water has different sources such as groundwater and aquifers, surface water, sea and ocean. In its purest form, water is colorless, odorless and tasteless; and should also be free from hazardous compounds [1,2]. Although water availability is not a problem on a global scale, there might be a problem of finding an adequate supply of fresh water that meets the ever-increasing demand; and maintaining its quality is becoming a great challenge [3].

Water could be exposed to different contaminants on its sources as or its way of the journey with elements created by human activities, effluents from chemical industries, human and animal waste, dissolved gases, etc. In addition, water contains some number of mineral constituents such as iron, magnesium, lithium, zinc, copper, chromium, nickel, cobalt, vanadium, arsenic, molybdenum, selenium, lead and so many other elements [4-7].

Heavy metals enter our body through drinking, eating, inhaling, and skin and eye contact. Once they enter into the body, they can damage at the cellular level by causing hazardous free radicals production that can cause cancer and many other diseases. Unlike organic pollutants, the majority of which are susceptible to biological degradation and do not degrade into harmless end products $[8,9]$. The removal of heavy metal effectively from water and wastewater is ecologically benign. There are many reported and established conventional methods for the recovery of heavy metal ions from wastewater, which included the chemical oxidation and reduction, ion exchange, filtration, electrochemical treatment, chemical precipitation, and evaporation. However, these hightechnology processes have significant disadvantages, which include incomplete metal removal, expensive equipment and monitoring systems, costly reagents, generation of toxic sludge and other waste products that require proper disposal [10-12].

In recent years, many types of research have been conducted to study low-cost agricultural waste as adsorbents for the removal of heavy metal ions from water sources. The advantage of using agricultural waste as raw materials for the production activated carbon is due to its low cost and renewable in nature [13]. These include peat [14], wood [15], pine bark [16], banana pith [17], soybean hulls [18], peanut shells [19], hazelnut shell [20], compost [21], rice husk and saw dust [22] are used as a precursor to prepare activated carbon.
Pumpkin is one of the most important vegetables grown worldwide. It is a gourd-like squash and belongs to the family of Cucurbitaceae's [23] Pumpkin seeds, also known as pepitas, are flat and variable in size, shape and color. The pumpkin seed has been used for the extraction of oil which has several benefits such as anti-microbial, anti-fungal and anti-viral properties. Survey related to pumpkin seed shell as a potential adsorbent suggest many researchers have worked on preparation and use it for removal of heavy metals [24-28]. But none of these articles reflect its use for the removal of $\mathrm{Cu}$ (II) and Cd (II) from aqueous solution. Thus, in the present study we have chosen pumpkin seed shell as a precursor of activated carbon for the removal of $\mathrm{Cu}$ (II) and Cd (II) ion.

\section{Experimental Methods}

\subsection{Materials}

All chemicals used were of analytical reagent grade and were used as received without any treatment. Distilled water was used for the preparation of the stock solution. Copper sulphate, $\mathrm{CuSO}_{4} \cdot 5 \mathrm{H}_{2} \mathrm{O}$ (Riedel-de Haën, Germany) ( $98 \%$ by wt.) and Cadmium chloride, $\mathrm{CdCl}_{2} \cdot 1 / 2 \mathrm{H}_{2} \mathrm{O}$ (Riedel-de Haën, Germany) (99\% by wt.) were used to prepare respective stock solutions. Further concentrations were prepared by progressive dilution using distilled water. $\mathrm{H}_{3} \mathrm{PO}_{4}$ (Riedel-de Haën, Germany) (85\% by wt.) was used as the activating agent. The instruments used in this works were: atomic absorption spectrophotometer (AAS) (Model analytic Jenanov AA 300), thermostatic water bath shaker (Model GRANT GLS 400, England), digital pH meter (HANNA instruments, $\mathrm{pH} 211$ ), electronic balance (ADAM AFP-110), Air drying oven (Model GENLAB WIDNES, England), electrical furnace (Model Nabertherm ${ }^{(\mathrm{R})}$ ), Scanning electron microscope (Model JSM 6510LV, JEOL Japan) and FTIR spectrophotometer (Spectrum 65 FTIR, Perkin Elmer model).

\subsection{Adsorbent Preparation and Activation}

Raw pumpkin seed shells were washed first with tap water and then with distilled water to remove the attached dust and other impurities. Washed PSS was dried at $105{ }^{\circ} \mathrm{C}$ for $12 \mathrm{~h}$, and grinded to powder. The powdered pumpkin seed shells were soaked with ortho-phosphoric acid $(85 \%$ by $v / v)$ by using the weight ratio of raw material and the acid at $1: 1$ $\mathrm{w} / \mathrm{v}$. The mixture was dried in an air-drying oven at $105^{\circ} \mathrm{C}$ for $24 \mathrm{~h}$. The dried PSS $/ \mathrm{H}_{3} \mathrm{PO}_{4}$ mixture was then put on to a crucible and placed in an electrical furnace for carbonization. The heating rate of carbonization was $10^{\circ} \mathrm{C} / \mathrm{min}$ and continues until the final temperature of $800^{\circ} \mathrm{C}$ was attained and it was kept at this temperature for $3 \mathrm{~h}$. The produced activated carbon was then cooled down to room temperature, washed with $5 \%$ aqueous $\mathrm{NaOH}$ solution followed by distilled water several times until the $\mathrm{pH}$ of the 
washing becomes neutral. Finally, the activated carbon prepared was dried at $105{ }^{\circ} \mathrm{C}$ for $12 \mathrm{~h}$ and grinded to powder into $150 \mu \mathrm{m}$ sieve size and kept it in an air tight container for further use in adsorption experiments.

\subsection{Batch Adsorption Experiments}

Batch adsorption experiments were carried out using a set of volumetric flask. A known amount of PSSAC $(0.2 \mathrm{~g})$ was kept into flasks containing various concentrations of $\mathrm{Cu}$ (II) and $\mathrm{Cd}$ (II) aqueous solutions. $\mathrm{pH}$ of the solution was adjusted to the desired value by adding $\mathrm{HCl}$ or $\mathrm{NaOH}$. The flasks were then shaken at room temperature using a shaker for a certain period so that the equilibrium is attained. The solutions were filtered and metal ion concentrations were determined by AAS method. Contact time (10 - $90 \mathrm{~min})$, solution $\mathrm{pH}(1-9)$, adsorbent dose $(0.05-0.30$ g), and effects of initial concentration (0.002-5 mg/L) for both $\mathrm{Cu}$ (II) and Cd (II) were studied.

\subsection{Adsorption Experiments}

The adsorption process provides vital information about the mechanism of reaction between adsorbate and adsorbent. Equilibrium adsorptions are described by isotherms governing the distribution of a given adsorbate between the liquid phase and the adsorbent where, Freundlich and Langmuir models were developed and used to analyze the data for the adsorption of the ions by pumpkin seed shell activated carbons. A kinetics study was carried out using Lagergren pseudo-first order and pseudo second order kinetic models to determine the equilibrium time required for the uptake of metals from a liquid solution [29]. Thermodynamic parameters such as Gibbs free energy $\left(\Delta \mathrm{G}^{\circ}\right)$, enthalpy $\left(\Delta \mathrm{H}^{\circ}\right)$ and entropy $\left(\Delta \mathrm{S}^{\circ}\right)$ of adsorption were evaluated. The amount of $\mathrm{Cu}$ (II) and Cd (II) adsorbed at a time t, $\mathrm{q}_{\mathrm{t}}(\mathrm{mg} / \mathrm{g})$ was calculated using Eq.(1).

$$
q_{t}=\frac{\left(c_{o}-C_{t}\right) V}{W}
$$

where $C_{t}(\mathrm{mg} / \mathrm{L})$ is the liquid phase concentrations of metal ion at any time, $\mathrm{C}_{0}(\mathrm{mg} / \mathrm{L})$ corresponds to the initial concentration of each metal ion. $\mathrm{V}(\mathrm{L})$, volume of the solution and $\mathrm{W}(\mathrm{g})$, mass of the adsorbent. Under the experimental conditions, the adsorption capacity $\left(q_{\mathrm{e}}\right)$, of the adsorbent for each concentration of $\mathrm{Cu}$ (II) and $\mathrm{Cd}$ (II) ions at equilibrium were calculated using Eq.(2),

$$
q_{e}=\frac{\left(C_{o}-C_{e}\right) V}{W}
$$

where $\mathrm{C}_{0}(\mathrm{mg} / \mathrm{L})$ corresponds to the initial concentration of each metal ion, and $\mathrm{C}_{\mathrm{e}}(\mathrm{mg} / \mathrm{L})$ to the concentration at equilibrium. The removal efficiency percentage of $\mathrm{Cu}$ (II) and Cd (II) ions was calculated for each run by using Eq.(3),

$$
\operatorname{Removal}(\%)=\frac{\left(C_{o}-C_{e}\right)}{C_{o}} \times 100
$$

\section{Results and Discussion}

\subsection{Characterization of The Activated Carbon}

The proximate analyses of PSS-AC as presented in Table 1 showed a lower amount of moisture, ash and volatile matter, indicating that the particle density is relatively small and that the biomaterial should be an excellent raw material for adsorbents to be used in the adsorption process. Ash content can also affect activated carbon i.e. it reduces the overall activity of activated carbon. It also reduces the efficiency of reactivation, the lower the ash value therefore the better the activated carbon for use as an adsorbent. Higher percentage adsorption for adsorbents having smaller particle size is due to the availability of more surface area [30].

Table 1 Proximate analysis of PSS-AC

\begin{tabular}{ll}
\hline Parameter & Value \\
\hline Moisture content (\%) & 10.06 \\
Volatile matter (\%) & 4.89 \\
Ash content (\%) & 21.01 \\
Fixed carbon (\%) & 74.1 \\
Mesh size $(\mu \mathrm{m})$ & 150 \\
$\mathrm{pH}$ & $6.5 \pm 1$ \\
\hline
\end{tabular}

\subsubsection{Fourier Transforms Infrared Characterization}

Fourier transforms infrared (FT-IR) spectrum analysis is one of the essential methods for the identification of the surface functional groups https://doi.org/10.30799/jespr.161.19050105 which can significantly enhance the adsorption efficiency of the prepared activated carbon by surface complexation. The spectrum in the near IR region (wave number: 4000-400 $\mathrm{cm}^{-1}$ ) of PSS-AC exhibits different absorption peaks indicating the presence of different functional groups. A peak around $2935 \mathrm{~cm}^{-1}$ was attributed to aliphatic methyl C-H stretching. The peak observed around $1465 \mathrm{~cm}^{-1}$ can be attributed to the $\mathrm{CH}_{3}$ bending and that observed around $1358 \mathrm{~cm}^{-1}$ was due to in-plane $\mathrm{C}-\mathrm{H}$ bending. The very weak absorption band which was observed at around $725 \mathrm{~cm}^{-1}$ was attributed to the long chain band of an aliphatic alkane. Fig. 1 and Table 2 below shows the FT-IR spectra of the activated carbon prepared from PSS$\mathrm{AC}$ before and after adsorption of $\mathrm{Cu}$ (II) and Cd (II) ions.

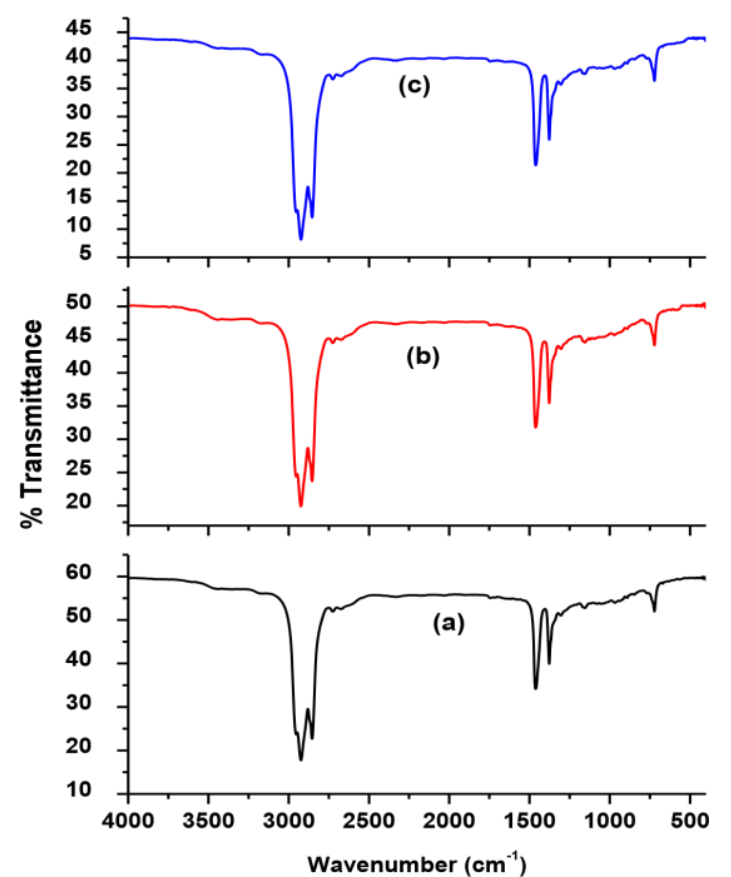

Fig. 1 FT-IR spectra of PSS-AC (a) before adsorption, (b) after adsorption of Cd (II) and (c) $\mathrm{Cu}(\mathrm{II})$ ions

Table 2 The FT-IR Spectral Characteristics of PSS-AC before and after adsorption of $\mathrm{Cd}$ (II) and $\mathrm{Cu}$ (II)

\begin{tabular}{lllll}
\hline Metal ion & Before & After & Difference & Functional groups \\
\hline Cu (II) & 2935 & 2924 & 11 & C-H stretching \\
Cd (II) & & 2924 & 11 & \\
Cu (II) & \multirow{2}{*}{1465} & 1461 & 4 & $\mathrm{CH}_{3}$ bending \\
$\mathrm{Cd}(\mathrm{II})$ & & 1462 & 3 & \\
$\mathrm{Cu}(\mathrm{II})$ & \multirow{2}{*}{1358} & 1356 & 2 & in-plane C-H bending \\
$\mathrm{Cd}$ (II) & & 1356 & 2 & \\
$\mathrm{Cu}$ (II) & \multirow{2}{*}{725} & 722 & 3 & long chain band of \\
$\mathrm{Cd}(\mathrm{II})$ & & 722 & 3 & aliphatic alkane \\
\hline
\end{tabular}
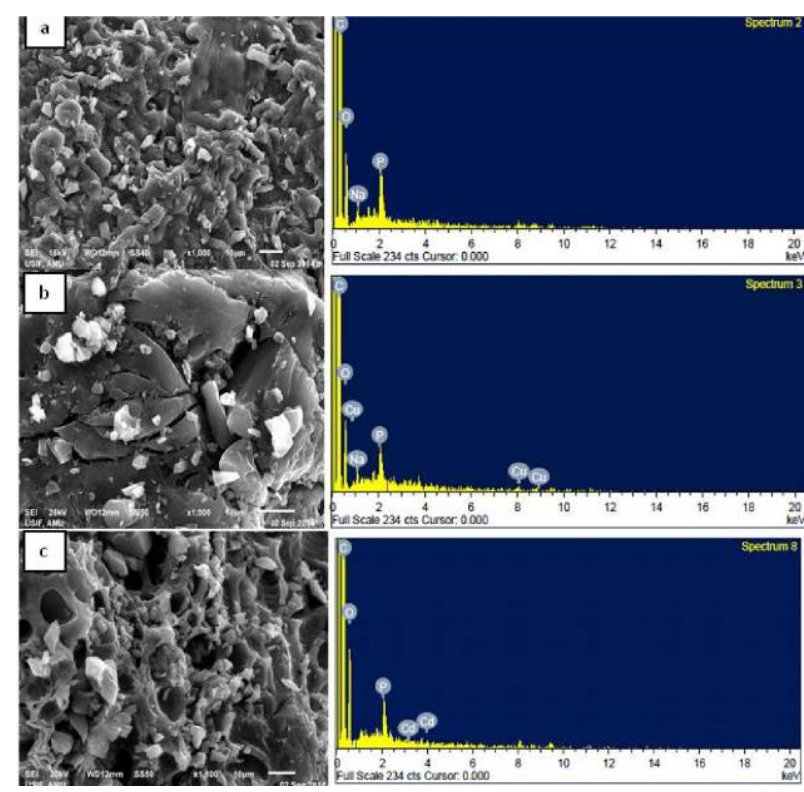

Fig. 2 SEM photographs \& EDX analysis for PSS-AC:(a) unloaded, (b) loaded with Cu (II) and (c) loaded with Cd (II) 


\subsubsection{Scanning Electron Microscope (SEM) and EDX Analysis}

The SEM micrographs of PSS-AC, Figs. 2(a-c), shows the surface having small cavities, pores and more rough surfaces indicating the presence of the interconnected porous network.

SEM micrographs of $\mathrm{Cu}$ (II) loaded PSS-AC shows that the surface is pitted and fragmented due to the $\mathrm{Cu}$ (II) uptake. The surface areas of $\mathrm{Cd}$ (II) loaded PSS-AC is found to be enhanced by the presence of more porosity, which can hold more solute from solution during adsorption. Figs. 2(a-c) EDX analysis was performed to determine the elemental composition of the activated carbon before and after metal ion adsorption implies the ability of the PSS-AC for Cu (II) and Cd (II) ions binding.

\subsection{Adsorption Experiments}

\subsubsection{Effect of Initial Metal Ion Concentration}

This effect was conducted to find the optimum concentration for the removal of metal ions from solutions. To find the optimum concentrations and time for the removal of the $\mathrm{Cu}$ (II)and $\mathrm{Cd}$ (II) ions, ten conical flasks containing $0.2 \mathrm{~g}$ of PSS-AC within $25 \mathrm{~mL}(0.01 \mathrm{mg} / \mathrm{L}, 0.05 \mathrm{mg} / \mathrm{L}, 0.2 \mathrm{mg} / \mathrm{L}$, $2 \mathrm{mg} / \mathrm{L}$ and $5 \mathrm{mg} / \mathrm{L})$ of $\mathrm{Cu}$ (II) and $(0.002 \mathrm{mg} / \mathrm{L}, 0.005 \mathrm{mg} / \mathrm{L}, 0.04 \mathrm{mg} / \mathrm{L}$, $0.2 \mathrm{mg} / \mathrm{L}$ and $1 \mathrm{mg} / \mathrm{L}$ ) of Cd (II) solutions were taken. The result of initial metal ion concentrations for the removal of $\mathrm{Cu}$ (II) and $\mathrm{Cd}$ (II) from aqueous solution is demonstrated in Fig. 3 below. It clearly indicates the percent adsorption was increased from $90.58 \%$ to $98.81 \%$ for $\mathrm{Cu}$ (II) with an increase of initial metal ion concentration from $0.01 \mathrm{mg} / \mathrm{L}$ to $5 \mathrm{mg} / \mathrm{L}$; and it increased from $93.52 \%$ to $98.99 \%$ for Cd (II) with increasing initial metal ion concentration from $0.002 \mathrm{mg} / \mathrm{L}$ to $1 \mathrm{mg} / \mathrm{L}$. It also depicts that the adsorption equilibrium was reached for $\mathrm{Cu}$ (II) at the optimum time of $70 \mathrm{~min}$ at $0.2 \mathrm{mg} / \mathrm{L}$ and for that of Cd (II) the optimum time was of $50 \mathrm{~min}$ at $0.005 \mathrm{mg} / \mathrm{L}$. It should be attributed to the fact that at lower concentrations, the metal-ions adsorption occurred a slow and further increase in concentration initiates a competition for available bonding sites on the PSS-AC surface by the metal ions and thus increased the adsorption [31].
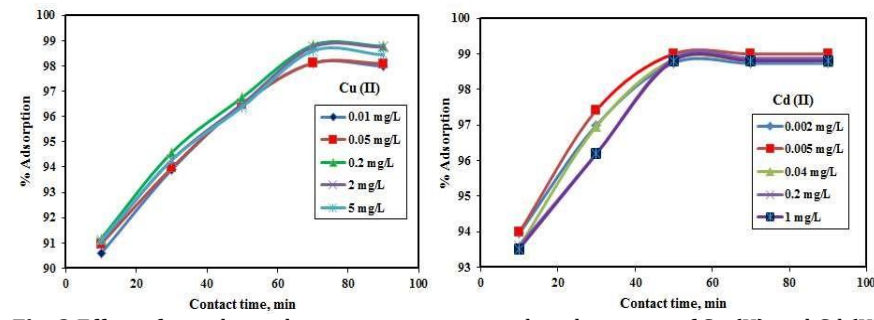

Fig. 3 Effect of initial metal ion concentration on the adsorption of Cu (II) and Cd (II) using PSS-AC

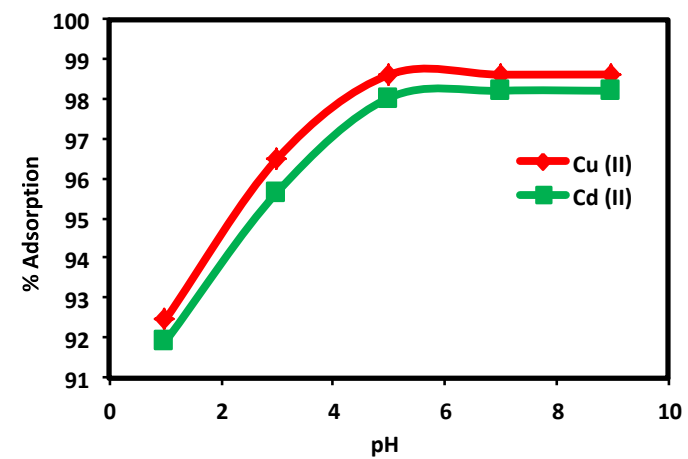

Fig. 4 Effect of $\mathrm{pH}$ on the adsorption of $\mathrm{Cu}$ (II) and Cd (II) using PSS-AC

\subsubsection{Effect of $p H$}

$\mathrm{pH}$ is one of the important controlling parameters for the removal of heavy metal ions from solutions because it affects the solubility of the metal ions, concentration of the counter ions on the functional group of the adsorbent and the degree of ionization of the adsorbate during the reaction process. The effect of $\mathrm{pH}$ on the adsorption of $\mathrm{Cu}$ (II) and Cd (II) from solution containing $0.2 \mathrm{~g}$ PSS-AC was studied by taking optimum concentrations of the metal ion $(0.2 \mathrm{mg} / \mathrm{L}$ at $70 \mathrm{~min}$ for $\mathrm{Cu}$ (II) and 0.005 $\mathrm{mg} / \mathrm{L}$ at $50 \mathrm{~min}$ for Cd (II)) shaking at $140 \mathrm{rpm}$ by varying the $\mathrm{pH}$ of the system between 1 to 9 . Desired value of $\mathrm{pH}$ was adjusted by drop wise addition of aqueous $5 \% \mathrm{NaOH}(\mathrm{w} / \mathrm{v})$ and/or $5 \% \mathrm{HCl}(\mathrm{v} / \mathrm{v})$. Fig. 4 below shows the effect of $\mathrm{pH}$ on adsorption percentage of $\mathrm{Cu}$ (II) and Cd (II) using PSS-AC. It can be seen from the figure that the percent adsorption of $\mathrm{Cu}$ (II) increases from $92.45 \%$ to $99.85 \%$ with increasing $\mathrm{pH}$ from 1 to 5 . After that it reaches equilibrium and it had a fractional deviation from one https://doi.org/10.30799/jespr.161.19050105 another. It can also be seen from Fig. 4 that the percent adsorption for $\mathrm{Cd}$ (II) increases from $91.9 \%$ to $98.9 \%$ with increasing $\mathrm{pH}$ from 1 to 5 . The maximum adsorption percentage obtained was $98.9 \%$ at $\mathrm{pH} 5$.

\subsubsection{Effect of Adsorbent Dose}

The removal efficiency and specific uptake of metals depend on the type and quantity of the adsorbent. The dosage of adsorbent is a key parameter to control both availability and accessibility of adsorption sites. Raise in quantity of $\mathrm{AC}$ increases the deduction percentage of both $\mathrm{Cu}$ (II) and $\mathrm{Cd}$ (II). This was due to extra surface area existing on the adsorbent and thus makes the penetration of the ions easier to the adsorption sites [32]. The effect of adsorbent dosage on the removal of $\mathrm{Cu}$ (II) and Cd (II) has been presented in Fig. 5 below. It is clear from the figure that the percent removal increases with a rise in the carbon dosage. After a certain dose it was found that it reaches equilibrium and had a fractional deviation from one another. It also depicts that the percent adsorption was increasing from $97.405 \%$ to $98.995 \%$ for Cu (II) and from $97.42 \%$ to $98.96 \%$ for Cd (II) at $0.2 \mathrm{~g}$ of carbon dose; the percent adsorption was insignificant around $98.99 \%$ for Cu (II) ion and around $98.96 \%$ for the Cd (II) ion.

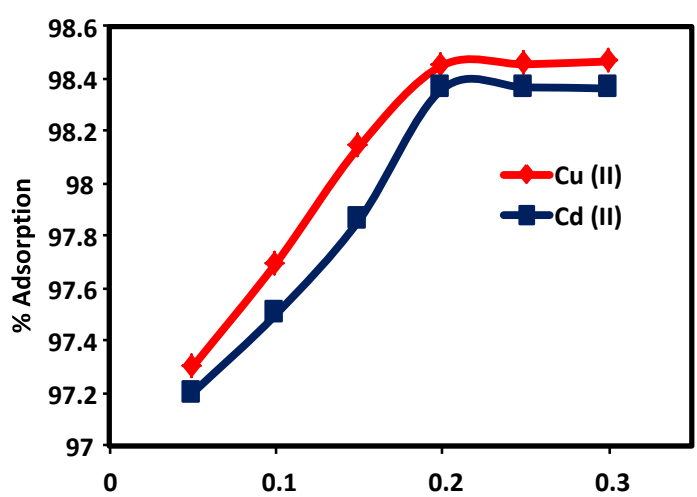

Fig. 5 Effect of adsorbent dose on the removal efficiency of $\mathrm{Cu}$ (II) and Cd (II) using PSS-AC

\subsubsection{Effect of Temperature}

In order to investigate the effect of temperature on the adsorption process, the batch adsorptions were done at different temperatures (from $25^{\circ} \mathrm{C}-45^{\circ} \mathrm{C}$ ) by mixing $0.2 \mathrm{~g}$ of activated carbon with $25 \mathrm{~mL}$ of $0.2 \mathrm{Cu}$ (II) $\mathrm{mg} / \mathrm{L}$ and $0.005 \mathrm{mg} / \mathrm{L}$ of Cd (II) solution at the optimal pH. From the results in Fig. 6, it is noted that the $\mathrm{Cu}$ (II) and $\mathrm{Cd}$ (II) adsorption has a steady increase with increasing solution temperature from $25^{\circ} \mathrm{C}$ to $45^{\circ} \mathrm{C}$, indicating that the adsorption is an endothermic process. Percentage adsorption for both $\mathrm{Cu}$ (II) and Cd (II) ions was optimum at $30{ }^{\circ} \mathrm{C}$ and it had insignificant increase above this temperature.

This implies that increasing temperature creates a wider surface area for adsorption at the adsorbent. In addition, at high temperature due to bond rupture of functional groups on the adsorbent, be an increase in a number of active adsorption sites, which may also lead to enhanced adsorption with the rise in temperature [33].

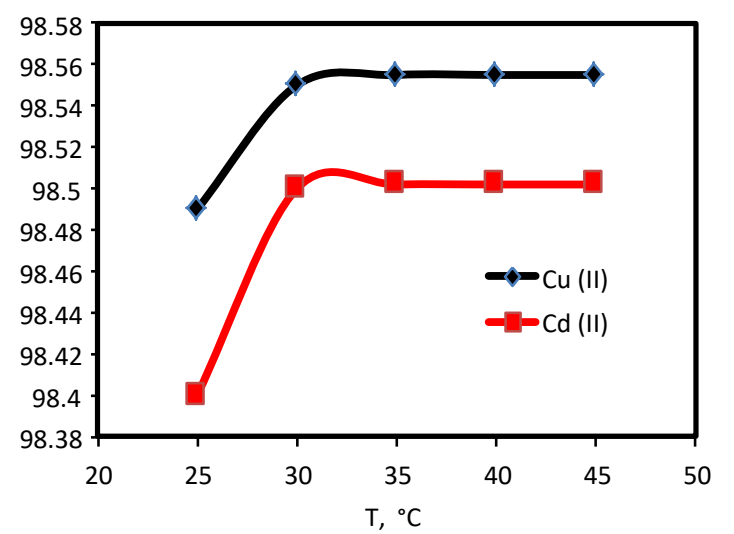

Fig. 6 Effect of temperature on removal efficiency of $\mathrm{Cu}$ (II) and Cd (II) ions using PSS-AC

\subsection{Adsorption Isotherms}

Adsorption isotherm is an important requirement for the design of an adsorption system that can provide information on the capacity of the adsorbent. The equilibrium study for the present work has been conducted based on the early and commonly used monolayer and 
multilayer adsorption isotherm models called Langmuir model and Freundlich model respectively.

\subsubsection{Langmuir Isotherm Model}

The Langmuir adsorption isotherm model is the best known of all other isotherm models that describe the adsorption process and it has been successfully applied to many adsorption processes. Weber and Chakravorti [34] expressed the Langmuir equation with its essential characteristics and the feasibility of the process in terms of a dimensionless constant separation factor or equilibrium parameter $\mathrm{R}_{\mathrm{L}}$ obtained from Eq.(4); the Langmuir equation was modeled equation,

$$
\frac{C_{e}}{q_{e}}=\frac{C_{e}}{q_{m}}+\frac{1}{q_{m} b_{L}}
$$

where $\mathrm{C}_{\mathrm{e}}(\mathrm{mg} / \mathrm{L})$ is the equilibrium concentration of $\mathrm{Cu}$ (II) and $\mathrm{Cd}$ (II) in solution, $\mathrm{q}_{\mathrm{e}}(\mathrm{mg} / \mathrm{g})$ is the amount each ion adsorbed at equilibrium from the solution on the adsorbent. Linear plots of $\mathrm{C}_{\mathrm{e}} / \mathrm{q}_{\mathrm{e}}$ versus $\mathrm{C}_{\mathrm{e}}$ for Langmuir model with a straight line of slope $1 / \mathrm{q}_{\mathrm{m}}$ and intercept of $1 / \mathrm{q}_{\mathrm{m}} \mathrm{b}_{\mathrm{L}}$ is obtained as shown in Fig. 7 where it is clearly seen that an excellent linear relationship exists for both metals indicating that the copper and cadmium adsorption on the PSS-AC follow the Langmuir adsorption isotherm. The values of $q_{\mathrm{m}}$ and $\mathrm{b}_{\mathrm{L}}$ were calculated from the slopes and the intercepts of lines in Fig. 7, shown in Table 3. The essential characteristics of the Langmuir equation can be expressed in terms of a dimensionless factor, $\mathrm{R}_{\mathrm{L}}$,

$$
R_{L}=\frac{1}{1+b_{L} C_{o}}
$$

where $R_{L}$ values indicate the type of adsorption either unfavorable $\left(\mathrm{R}_{\mathrm{L}}>1\right)$, linear $\left(\mathrm{R}_{\mathrm{L}}=1\right)$, favorable $\left(0<\mathrm{R}_{\mathrm{L}}<1\right)$ or irreversible $\left(\mathrm{R}_{\mathrm{L}}=0\right)$.
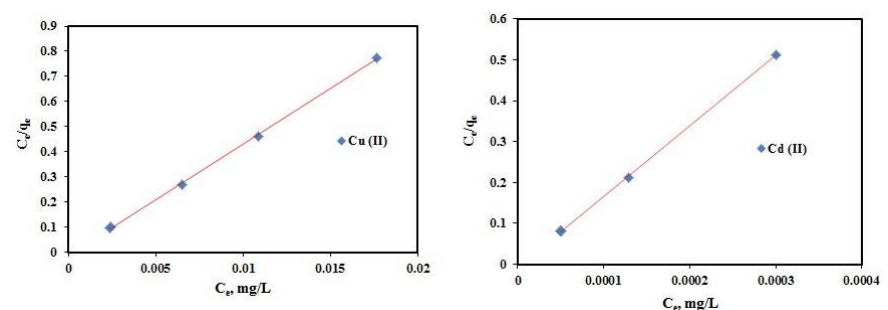

Fig. 7 Langmuir plot for adsorption of $\mathrm{Cu}$ (II) and Cd (II) using PSS-AC

\subsubsection{Freundlich Isotherm Model}

Freundlich isotherm gives the relationship between equilibrium liquid and solid phase capacity based on the multilayer adsorption properties consisting of a heterogeneous surface of the adsorbent. This isotherm is derived from the assumption that the adsorption sites are distributed exponentially with respect to the heat of adsorption [35]. Freundlich equation does not consider all sites on the adsorbent surface to be equal rather it assumes that, once the surface is covered, additional adsorbed species can still be accommodated [36]. The Freundlich equation is,

$$
\log q_{e}=\log K_{f}+\frac{1}{n} \log C_{e}
$$

where $\mathrm{K}_{\mathrm{f}}(\mathrm{mg} / \mathrm{g})$ and $\mathrm{n}$ are Freundlich constants incorporating all factors affecting the adsorption process such as adsorption capacity and intensity of the adsorption.
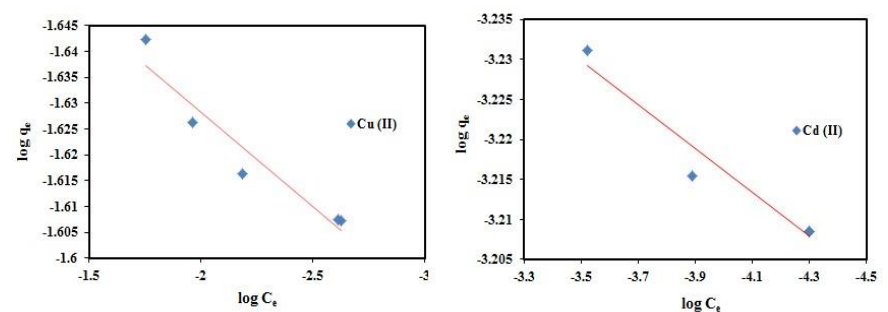

Fig. 8 Freundlich plot for Cu (II) (a) and Cd (II) (b) removal using PSS-AC

The Freundlich isotherm plot, log qe versus log Ce, is shown in Fig. 8 below. $\mathrm{K}_{\mathrm{f}}$ and $1 / \mathrm{n}$ values can be obtained from the intercept and slope of the straight line. The exponent (n) is an index of the diversity of free energies associated with the sorption of the solute by multiple components of a heterogeneous sorbent. When $\mathrm{n}<1$, the isotherm is concave and adsorbates are bound with weaker and weaker free energies, $\mathrm{n}>1$, the isotherm is convex and more sorbate presence in the sorbent https://doi.org/10.30799/jespr.161.19050105 enhance the free energies of further sorption and $n=1$, the isotherm is linear and system has a constant free energy at all adsorbate concentrations.

In the present study, the value of $n$ at equilibrium was below unity, suggesting favorable adsorption. Furthermore, the values of the dimensionless factor, $R_{L}$, were between 0 and 1 . This also suggested favorable adsorption of $\mathrm{Cu}$ (II) and Cd (II) ions using PSS-AC.

Table 3 Results of isotherm models for the removal of $\mathrm{Cu}$ (II) and Cd (II) ions using PSS-AC at $30{ }^{\circ} \mathrm{C}$

\begin{tabular}{llllllll}
\hline Heavy & \multicolumn{2}{l}{ Langmuir isotherm } & \multicolumn{4}{l}{ Freundlich isotherm } \\
metal ion & $\mathrm{q}_{\mathrm{m}}(\mathrm{mg} / \mathrm{g})$ & $\mathrm{b}_{\mathrm{L}}\left(\mathrm{dm}^{3} / \mathrm{g}\right)$ & $\mathrm{R}^{2}$ & $\mathrm{~K}_{\mathrm{f}}(\mathrm{mg} / \mathrm{g})$ & $1 / \mathrm{n}(\mathrm{L} / \mathrm{mg}) \mathrm{R}^{2}$ & $\mathrm{R}_{\mathrm{L}}$ \\
\hline $\mathrm{Cu}(\mathrm{II})$ & 43.48 & 76.56 & 0.9997 & -0.0365 & 0.588 & 0.961 & 0.061 \\
$\mathrm{Cd}(\mathrm{II})$ & 172 & 1656 & 0.9999 & -0.027 & 0.300 & 0.976 & 0.11 \\
\hline
\end{tabular}

\subsection{Adsorption Kinetic Studies}

The adsorption kinetics describing the contact time in the removal of $\mathrm{Cu}$ (II) and Cd (II) is one of the characteristics defining efficiency of the adsorption. The adsorption kinetics of adsorbent depends on the properties of the adsorbate, the experimental conditions, temperature, concentrations and $\mathrm{pH}$ values. Each combination of adsorbent and adsorbate has a unique metal ion-adsorbent interaction. To explain adsorption kinetics of $\mathrm{Cu}$ (II) and Cd (II) ions by PSS-AC at $30{ }^{\circ} \mathrm{C}$ both pseudo-first order and pseudo-second order kinetic models were adopted.

\subsubsection{Pseudo-First Order}

The values of $\mathrm{q}_{\mathrm{e}}$ and $\mathrm{K}_{1}$ for the pseudo-first order kinetic model was determined from the intercepts and the slopes of the plots of $\log \left(\mathrm{q}_{\mathrm{e}}-\mathrm{q}_{\mathrm{t}}\right)$ versus time, respectively from Figure 9. The linear form of the pseudo-first order equation was generally expressed as Eq.(7),

$$
\log \left(\mathbf{q}_{e}-\mathbf{q}_{t}\right)=\log \mathbf{q}_{e}-\frac{K_{f}}{2.303} t
$$

where $\mathrm{q}_{\mathrm{e}}$ and $\mathrm{q}_{\mathrm{t}}$ are the values of amount adsorbed per unit mass (mg/g) at equilibrium and at any time $t$ respectively, and $K_{f}$ is the pseudo first order sorption rate constant $\left(\mathrm{min}^{-1}\right)$. The $\mathrm{K}_{\mathrm{f}}$ value could be obtained by plotting $\log \left(\mathrm{q}_{\mathrm{e}}-\mathrm{q}_{\mathrm{t}}\right)$ versus $\mathrm{t}$. In order to find a more reliable description of the kinetics, second order kinetic equation was applied as the linear [37].
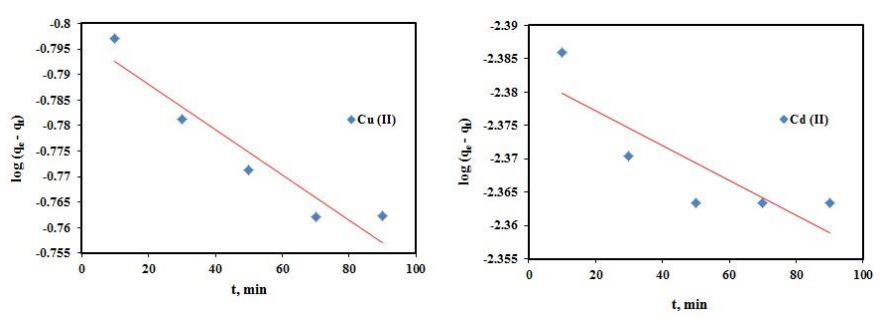

Fig. 9 Pseudo-first order sorption kinetics of Cu (II) and Cd (II) using PSS-AC

\subsubsection{Pseudo-Second Order}

The procedure for the pseudo-second order is more likely to predict the behavior over the whole range of adsorption process which was based on the assumption that the rate limiting step may be physisorption due to the presence of weak forces of attraction between adsorbent and adsorbate.

$$
\frac{t}{q_{t}}=\frac{1}{k q_{e}^{2}}+\frac{t}{q_{e}}
$$

where $\mathbf{k}_{\text {s }}$ is rate constant for the second order kinetics ( $\mathrm{g} \mathrm{mg} / \mathrm{min}$ ).
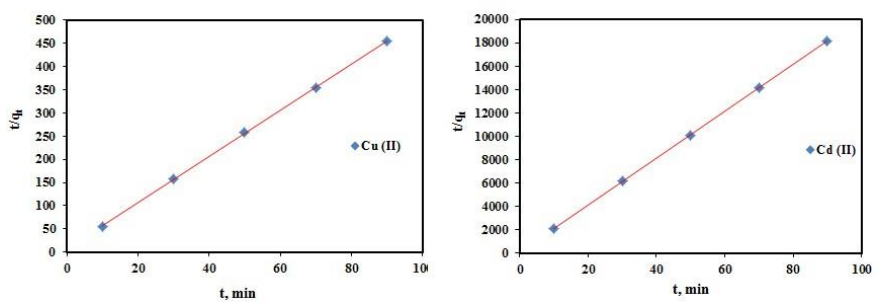

Fig. 10 Pseudo-second order sorption kinetics of Cu (II) and Cd (II) using PSS-AC

The pseudo-second-order plot of $t / q_{t}$ versus $t$ is a straight line as shown in Fig. $10 . \mathrm{K}_{2}$ and $\mathrm{q}_{\mathrm{e}}$ values determined from the slopes and intercepts of the plot respectively are presented in Table 4 . The results indicate that the 
kinetic behavior of $\mathrm{Cu}$ (II) and Cd (II) adsorption on activated carbon from pumpkin seed shells can be satisfactorily explained with the pseudosecond order adsorption equation.

Table 4 Kinetics parameters for the adsorption of Cu (II) and Cd (II) using PSS-AC at $303 \mathrm{~K}$

\begin{tabular}{|c|c|c|c|c|c|c|c|}
\hline \multirow[b]{2}{*}{$\begin{array}{l}\text { Heavy } \\
\text { metal ion }\end{array}$} & \multicolumn{4}{|c|}{ Pseudo-first order } & \multicolumn{3}{|c|}{ Pseudo second order } \\
\hline & $\begin{array}{l}\mathrm{q}_{\mathrm{e}} \text { exp. } \\
(\mathrm{mg} / \mathrm{L})\end{array}$ & $\begin{array}{l}\mathrm{q}_{\mathrm{e}} \mathrm{cal} \\
(\mathrm{mg} / \mathrm{L})\end{array}$ & $\begin{array}{l}\mathrm{K}_{1} \\
\left(\times 10^{-4} \mathrm{~min}^{-1}\right)\end{array}$ & $\mathrm{R}^{2}$ & $\begin{array}{l}\mathrm{q}_{\mathrm{e}} \mathrm{cal} \\
(\mathrm{mg} / \mathrm{L})\end{array}$ & $\begin{array}{l}\mathrm{K}_{2} \\
(\mathrm{~g} / \mathrm{mg} \min )\end{array}$ & $\mathrm{R}^{2}$ \\
\hline$\overline{\mathrm{Cu} \text { (II) }}$ & 2.5 & 0.0227 & 4.438 & 0.952 & 2.45 & 4.985 & 0.9999 \\
\hline Cd (II) & 6.19 & 0.054 & 2.61 & 0.841 & 5.58 & 200.46 & 0.9999 \\
\hline
\end{tabular}

exp. (Experimental result), cal. (Calculated values)

\subsection{Thermodynamic Study}

The thermodynamic parameters that help us to understand the nature of the adsorption process of the heavy metals, such as standard Gibbs free energy change $\left(\Delta \mathrm{G}^{\circ}\right)$, enthalpy changes $\left(\Delta \mathrm{H}^{\circ}\right)$ and entropy change $\left(\Delta \mathrm{S}^{\circ}\right)$ were calculated to evaluate thermodynamic feasibility to confirm the nature of the adsorption process. The enthalpy value for adsorption process may be used to distinguish between chemical and physical adsorption. For chemical adsorption, values of enthalpy change range from 83 to $830 \mathrm{~kJ} / \mathrm{mol}$, while for physical adsorption they range from 8 to $25 \mathrm{~kJ} / \mathrm{mol}[38]$.

$$
\Delta \mathbf{G}^{\circ}=-\mathbf{R T} \ln \mathbf{K}_{c}
$$

The values of $\Delta \mathrm{H}^{\circ}(\mathrm{kJ} / \mathrm{mol})$ and $\Delta \mathrm{S}^{\circ}(\mathrm{kJ} / \mathrm{mol} / \mathrm{K})$ were calculated from the slope and intercept of the linear plot of $\ln \mathrm{K}_{\mathrm{c}}$ versus reciprocal of temperature 1/T Eq.(10).

$$
\ln K_{c}=\frac{\Delta S^{\circ}}{R}-\frac{\Delta H^{\circ}}{R T}
$$

where $\mathrm{R}$ is the gas constant ( $8.314 \mathrm{~J} / \mathrm{mol} . \mathrm{K})$, T is the absolute temperature in Kelvin $(\mathrm{K})$ and $K_{c}(\mathrm{~L} / \mathrm{g})$ is the standard thermodynamic equilibrium constant defined as $q_{e} / c_{e}$. The magnitude of Gibbs free energy change, obtained is negative demonstrating that the adsorption is rapid and spontaneous. The negative value of $\Delta \mathrm{G}^{\circ}$ ensures the feasibility of the process. Generally, $\Delta \mathrm{G}^{\circ}$ values range from 0 to $-20 \mathrm{KJ} / \mathrm{mol}$ for physical adsorption and -80 to $-400 \mathrm{KJ} / \mathrm{mol}$ for chemical adsorptions [39]. Thus, in this study the $\Delta G^{\circ}$ values are a negative number indicating that the adsorption is mainly physical. The values of $\Delta \mathrm{S}^{\circ}$ and $\Delta \mathrm{H}^{\circ}$ were obtained from the slope and intercept of a linear plot of $\operatorname{lnK}_{\mathrm{c}}$ against $1 / \mathrm{T}$, shown in Table 5.

The low values of $\Delta \mathrm{H}^{\circ}$ give clear evidence that the interaction between the metal ions and the PSS-AC was weak. On this basis, the adsorption concluded by $\mathrm{Cu}$ (II) and Cd (II) with PSS-AC is a physical adsorption process. The positive value of entropy, $\Delta S^{\circ}$ represents an increase in the degree of freedom of the adsorbed species and some changes that occur in the internal structure of PSS-AC during the adsorption process [40].

Table 5 Thermodynamic parameters for the adsorption of Cu (II) and Cd (II) using PSS-AC at different temperatures

\begin{tabular}{lllll}
\hline Heavy metal & $\mathrm{T}(\mathrm{K})$ & $\Delta \mathrm{G}^{\circ}(\mathrm{kJ} / \mathrm{mol})$ & $\Delta \mathrm{H}^{\circ}(\mathrm{kJ} / \mathrm{mol})$ & $\Delta \mathrm{S}^{\circ}(\mathrm{kJ} / \mathrm{mol} . \mathrm{K})$ \\
\hline Cu (II) & 298 & -5.309 & 2.595 & 70.886 \\
& 303 & -5.398 & & \\
& 308 & -5.487 & & \\
& 313 & -5.576 & & \\
\hline Cd (II) & 318 & -5.665 & & 16.956 \\
& 298 & -5.052 & 0.3608 & \\
& 303 & -5.136 & & \\
& 308 & -5.222 & & \\
& 313 & -5.306 & & \\
& 318 & -5.391 & & \\
\hline
\end{tabular}

\subsection{Desorption Study}

Desorption studies help to elucidate the nature of adsorption and recycling of the spent adsorbent. This process has been carried out by reagents as an extractant like $\mathrm{H}_{2} \mathrm{SO}_{4}, \mathrm{HNO}_{3}$, acetic acid and $\mathrm{HCl}$. Desorption process performed by mixing an appropriate amount of solvent along with the spent adsorbents and shaken together for a fixed time and then filter to separate the adsorbent and adsorbate.

In this study $\mathrm{HCl}$ a comparatively inexpensive solvent was used to perform desorption process. Various concentration of $\mathrm{HCl}(0.5,1,2$ and 3 mol/L) was mixed with the spent adsorbent loaded with copper and cadmium ions and agitated for half an hour. After that the solution was filtered to separate the adsorbent and adsorbate. The concentration of the https://doi.org/10.30799/jespr.161.19050105 filtrate was measured and desorption efficiency was calculated using the given formula. Data obtained are reported in Table 6 given below.

$$
\text { Desorption Efficiency }(\%)=\frac{\text { released metal concentration }}{\text { initially sorbed metal concentration }} x 100
$$

Table 6 Desorption of Cu (II) and Cd (II) from loaded PSSAC

\begin{tabular}{llllll}
\hline Metal Ions & Removal & \multicolumn{5}{l}{ HCl Concentration (mol/L) } \\
\cline { 3 - 6 } & efficiency & 0.5 & 1 & 2 & 3 \\
\hline Cu (II) & 98.81 & 70 & 80 & 85 & 82 \\
Cd (II) & 98.99 & 65 & 75 & 80 & 78 \\
\hline
\end{tabular}

The result of the desorption study suggests that the reuse pertaining to PSSAC increases with increasing concentration of $\mathrm{HCl}$ until $2 \mathrm{~mol} / \mathrm{L}$ beyond this decrease is observed in desorption efficiency for the metal ions.

\section{Conclusion}

It is concluded from this study that adsorption is a valuable tool for controlling the level of aqueous $\mathrm{Cu}$ (II) and $\mathrm{Cd}$ (II) pollution. Characterization of $\mathrm{H}_{3} \mathrm{PO}_{4}$ activated pumpkin seed shells using FT-IR showed slight differences in the peaks due to the presence of functional groups before and after adsorption of $\mathrm{Cu}$ (II) and Cd (II) ions. The majority of the functional groups were aromatic carbon containing in both the cases. The SEM analysis clearly indicates significant changes to the surface morphology; and EDX analysis determines the elemental composition of the adsorbent before and after adsorption of the metals. The adsorption of $\mathrm{Cu}$ (II) and Cd (II) using PSS-AC is found to be contact time, initial metal ion concentration, $\mathrm{pH}$ and adsorbent dose dependent. The adsorption kinetics provides a better correlation of the sorption data by a pseudosecond order kinetic model than the pseudo-first order model for both metals; this suggests that the pseudo-second order model satisfactorily describe the adsorption process. The Langmuir adsorption isotherm model was better used to represent the experimental data. Adsorption was increased with increasing initial metal ions concentrations and adsorbent. The thermodynamic parameters $\Delta \mathrm{G}^{\circ}, \Delta \mathrm{H}^{\circ}$ and $\Delta \mathrm{S}^{\circ}$ showed a chemically favoured, spontaneous and endothermic adsorption.

\section{Acknowledgement}

Authors thankfully acknowledge the Department of Chemistry, CNS Jimma University, Jimma, Ethiopia for providing necessary facilities for carrying out this work.

\section{References}

[1] T. Krafft, Integrated management of water resources: Understanding the earth system: compartments, processes, and interactions Springer, COUNTRY, 2001.

[2] B. Staniškienė, P. Matusevičius, A. Urbonavičius, Distribution of heavy metals in muscles of fish: Concentrations and change tendencies, Environ. Res. Eng. Mgt. 48 (2009) 35-41.

[3] J. Stoler, J.R. Weeks, R.A. Otoo, Drinking water in transition: A multilevel crosssectional analysis of sachet water consumption in Accra, Plos One 8(6) (2013) 1-11.

[4] O.K. Hakam, H. Bounouira, A. Choukri, R. Cherkaoui, S. Chakiri, Determination of trace elements in Bouregreg river water by inductively coupled plasma mass spectrometry, Spectros. Lett. Int. J. Rapid Commun. 41 (2008) 267-272.

[5] A.A. Adepoju-Bello, 0.0. Ojomolade, G.A. Ayoola, H.A.B. Coker, Quantitative analysis of some toxic metals in domestic water obtained from Lagos metropolis, The Nig. J. Pharm. 42 (2009) 47-60.

[6] M. Tuzen, M. Soylak, Evaluation of metal levels of drinking waters from the Tokat-Black sea region of Turkey, Pol. J. Environ. Stud. 15 (2006) 915-919.

[7] O. Kaplan, N.C. Yildirim, N. Yildirim, N. Tayhan, Assessment of some heavy metals in drinking water samples of Tunceli, Turkey,E. J. Chem. 8 (2011) 276280.

[8] S.M. Al-Garni, Biosorption of lead by gram-ve capsulated and non-capsulated bacteria, Water SA. 31 (2005) 345-350.

[9] V.K. Gupta, M. Gupta, S. Sharma, Process development for the removal of lead and chromium from aqueous solutions using red mud-an aluminum industry waste, Water Res. 35 (2001) 1125-1134.

[10] J.W. Patterson, Wastewater treatment technology. Ann, Arbor Science Pub. Inc, USA, 1977.

[11] Z. Aksu, Biosorption of heavy metals by microalgae in batch and continuous systems, In: N. Tam, Y.S. Wong, (Eds.), Algae for waste water treatment, Springer-Verlag and Landes Bioscience, Germany, 1998, pp.37-53.

[12] Z. Aksu, F. Gonen, Z. Demircan, Biosorption of chromium (VI) ions by Mowital@B30H resin immobilized activated sludge in a packed bed: comparison with granular activated carbon, Process Biochem. 38 (2002) 175186.

[13] G. H. Pino, L.M. Souza de Mesquita, M.L. Torem, G.A.S. Pinto, Biosorption of cadmium by green coconut shell powder, Miner. Eng. 19 (2006) 380-387. 
[14] S.J. Allen, M. Murray, P. Brown, O. Flynn, Peat as an adsorbent for dyestuffs and metals in wastewater, Resour. Conservat. Recycl. 11(1-4) (1994) 25-39.

[15] V.J.P. Poots, G. McKay, J.J. Healy, Removal of basic dye from effluent using wood as an adsorbent, Water Pollut. Control Federat. 50(5) (1978) 926-935

[16] L. Cutillas-Barreiro, L. Ansias-Manso, D. Fernandez-Calvi, M. Arias-Estevez, J.C. NovoaMu noz, et al., Pine bark as bio-adsorbent for $\mathrm{Cd}, \mathrm{Cu}, \mathrm{Ni}, \mathrm{Pb}$ and $\mathrm{Zn}$ : Batchtype and stirred flow chamber experiments, J. Environ. Manag. 144 (2014) 258264.

[17] C. Namasivayam, N. Kanchana, Waste banana pith as adsorbent for color removal from wastewaters, Chemosphere 25(11) (1992) 1691-1705

[18] W.E. Marshall, L.H. Wartelle, D.E. Boler, T. Christopher, Metal ion adsorption by soybean hulls modified with citric acid: A comparative study, Environ. Technol. 21(6) (2000) 601-607

[19] W. Wafwoyo, C.W. Seo, W.E. Marshall, Utilization of peanut shells as adsorbents for selected metals, J. Chem. Technol. Biotechnol. 74 (1999) 1117-1121.

[20] M. Zhu, R. Liu, H. Chai, J. Yao, Y. Chen, Z. Yi, Hazelnut shell activated carbon: a potential adsorbent material for the decontamination of uranium(VI) from aqueous solutions, J. Rad. Nucl. Chem. 310 (2016) 1147-1154.

[21] L. Cundari, N.D. Isvaringga, Y.M. Arinda, Utilization of household organic compost in zinc adsorption system, AIP Conf. Proceed. 1903 (2017) 040018-17.

[22] K.A. Abdou, A.N. Mohammed, W.A. El Rahman Moselhy, A.A. Farghali, Assessment of modified rice husk and sawdust as bio-adsorbent for heavy metals removal using nano particles in fish farm, Asian J. Animal Veter. Adv. 13(2) (2018) 180188.

[23] S.Y. Hamed, N.M. El Hassan, A.B. Hassan, M.M. Eltayeb, E.E. Babiker, Nutritional evaluation and physiochemical properties of processed pumpkin (Telfairia occidentalis Hook) Seed flour, Pak. J. Nutr. 7 (2008) 330-334.

[24] A.I. Okoye, P.M. Ejikeme, O.D. Onukwuli, Lead removal from wastewater using fluted pumpkin seed shell activated carbon: Adsorption modeling and kinetics, Int. J. Environ. Sci. Tech. 7(4) (2000) 793-800.

[25] A.W. Verla, M. Horsfall (Jnr), E.N. Verla, A.I. Spiff, O.A. Ekpete, Preparation and characterization of activated carbon from fluted pumpkin (Telfairia Occidentalis Hook. F) seed shell, Asian J. Nat. Appl. Sci. 1(3) (2012) 39-50.

[26] I. Demiral, C.A. Samdan, Preparation and characterisation of activated carbon from pumpkin seed shell using $\mathrm{H}_{3} \mathrm{PO}_{4}$, Anadolu Univ. J. Sci. Technol. A: Appl. Sci. Eng. 17 (2016) 125-138.

[27] I. Demiral, C.A. Şamdan, H. Demiral, Production and characterization of activated carbons from pumpkin seed shell by chemical activation with $\mathrm{ZnCl}_{2}$, Desal. Water Treat. 57 (2016) 2446-2454
[28] T.O. Chime, C.C. Onyema, P.C.N. Ejikeme, Removal of lead from paint effluent using low cost activated adsorbent (fluted pumpkin seed shells), IJERT Int. J. Eng. Res. Technol. 5(9) (2016) 676-683.

[29] S.Y. Lagergren, The theory of so-called adsorption of dissolved substances, $\mathrm{K}$ Sven. Vetenskapsakad. Handl. 24(4) (1898) 1-39.

[30] T. Budinova, E. Ekinci, F. Yardin, A. Grimm, E. Björnbom, et al., Characterization and application of activated carbon produced by $\mathrm{H}_{3} \mathrm{PO}_{4}$ and water vapour activation, Fuel Proc. Tech. 87 (2006) 899-905.

[31] M.J. Horsfall, A.I. Spiff, Effect of metal ions concentration on the biosorption of $\mathrm{Pb}$ (II) and Cd (II) by Caladium bicolor, Afr. J. Biotech. 4 (2005) 191-196.

[32] M.A.O. Badmus, T.O.K. Audu, B. Anyata, Removal of lead ion from industrial wastewaters by activated carbon prepared from periwinkle shells (Typanotonus fuscatus), Turkish J. Eng. Env. Sci. 31 (2007) 251-263.

[33] F. Li, P. Du, W. Chen, S. Zhang, Preparation of silica supported porous sorbent for heavy metal ions removal in wastewater treatment by organic-inorganic hybridization combined with sucrose and polyethylene glycol imprinting, Anal. Chim. Acta 585 (2007) 211-218.

[34] T.W. Weber, R.K. Chakravorti, Pore and solid diffusion models for fixed bed adsorbents. AIChE J. 20 (1974) 228-238.

[35] T. Karthika, A. Thirunavukkarasu, S. Ramesh, Biosorption of Cu (II) from aqueous solutions using Tridax procumbens, Rec. Res. Sci. Technol. 2 (2010) 8691.

[36] M.F. Sawalha, J.R. Peralta-Videa, J. Romero-Gonzales, J.L. Gardea-Torresdey, Biosorption of Cd (II), Cr (III) and Cr (IV) by saltbush (Atriplex canescens) biomass: thermodynamic and isotherm studies, J. Colloid. Interf. Sci. 300 (2006) 100-104.

[37] N. Azouaou, Z. Sadaoui, A. Djaafri, H. Mokaddem, Adsorption of cadmium from aqueous solution using untreated coffee grounds: Equilibrium, kinetics and thermodynamics, J. Hazard Mater. 184 (2010) 126-134.

[38] A. Sar, M. Tuzen, O.D. Uluozlu, M. Soylak, Biosorption of Pb(II) and Ni(II) from aqueous solution by lichen (Cladonia furcata) biomass, Biochem. Eng. J. 37 (2007) 151-158.

[39] B.K. Hamad, A.M. Noor, A.A. Rahim, Removal of 4-chloro-2-methoxy phenol from aqueous solution by adsorption to oil palm shell activated carbon activated with $\mathrm{K}_{2} \mathrm{CO}_{3}$, J. Phys. Sci. 22 (2011) 39-55.

[40] Z.Z. Chowdhury, S.M. Zain, A.K. Rashid, Equilibrium isotherm modeling kinetics and thermodynamics Study for removal of lead from wastewater, E. J. Chem. 8 (2011) 333-339. 